\title{
ПОРІВНЯЛЬНИЙ АНАЛІЗ ФІНАНСУВАННЯ СФЕРИ ОХОРОНИ ЗДОРОВ'Я УКРАЇНИ ТА КРАЇН ЄВРОПЕЙСЬКОГО СОЮЗУ
}

\author{
Вінницький національний медичний університет \\ імені М. І. Пирогова, м. Вінниця, Україна
}

\begin{abstract}
Мета: здійснити порівняльний аналіз фрінансування сорери охорони здоров'я України та країн ЄС за останні роки.
Матеріали і методи. Використано теоретично-порівняльний, бібліосемантичний аналіз даних щодо фрінансування сорери охорони здоров'я в Україні та країнах $€ C$.

Результати. Проаналізовано наукові джерела вітчизняних, зарубіжних досліджень, законів України, концепцій державних програм і резолюцій ЄС та виділено основні проблеми незавершеної медичної ресрорми. Для успішного проведення реформи в сфері охорони здоров'я в Україні прийнято низку нормативно-правових актів. Позитивні зміни у реформі охорони здоров'я України безпосередньо залежать від видатків на охорону здоров'я у ВВП. Найбільше коштів на охорону здоров'я було спрямовано в 2013 р. - 4,23 \%, але у 2019 р. цей показник був найменшим за останні роки незалежності - 2,4 \% від ВВП. Різкі коливання у фрінансуванні сфери охорони здоров'я негативно впливають на створення нової Національної служби здоров'я України, на саму рефрорму в цілому, а також на показники тривалості життя населення в Україні. Позитивні приклади у рефрормі охорони здоров'я як Республіки Польща, так й інших європейських країн - відокремлення цільових коштів на охорону психічного здоров'я від бюджету, які належать органам місцевого самоврядування закладів охорони здоров'я, та вкрай необхідний закон про обов'язкове медичне страхування як у багатьох країнах світу. Психічне здоров'я населення Польщі та країн $€ C €$ одним із пріоритетних завдань і невід'ємною частиною у реформуванні сорери охорони здоров'я. У резолюції ВОО3, Ради ЄС, Ради Європи, починаючи з 1975 р., важливе значення відводять адекватному і справедливому інвестуванню в систему охорони психічного здоров'я, що позначається на здоров'ї населення планети. У 2019 р. ВООЗ зі Світовим банком проводили аналіз реформи фрінансування системи охорони здоров'я за 2016-2019 рр. для надання стратегічних рекомендацій щодо покращення надання медичних послуг.

Висновки. За результатами аналізу встановлено недосконалість фрінансування закладів охорони здоров'я України, що впливає на якість надання медичної допомоги та необхідність впровадження постійного коригування/ моніторингу ефективності діючої нової моделі фрінансування системи охорони здоров'я України і запровадження обов'язкового медичного страхування.
\end{abstract}

КЛЮчОВІ СЛОВА: фрінансування; охорона здоров'я; психічне здоров'я; медична реформа.

Особливо важливим питанням сучасної системи охорони здоров'я (О3) є забезпечення фрінансування сорери охорони здоров'я України, оскільки це має вплив на стан здоров'я населення України. У 2019 р. ВООЗ зі Світовим банком проводили аналіз реформи фрінансування системи охорони здоров'я за 2016-2019 рр. для надання стратегічних рекомендацій щодо шляхів подолання. Запропоновано головні напрямки для покращення продовження реформи в сорері охорони здоров'я: автоматизація надавачів медичних послуг та збільшення ролі місцевих органів самоврядування як власників закладів охорони здоров'я; впровадження стратегічних закупівель медичних послуг, оцінка перетворень на рівні первинної медичної допомоги 3 використанням циоррових технологій (запровадження електронної системи); розробка чітко визначеного гарантованого пакета медичних послуг.

Великий крок у зміцненні здоров'я населення Україна зробила, прийнявши Закон України «Про (C) B. В. Чорна, 2021 державні фрінансові гарантії медичного обслуговування населення» від 19.10. 2017 р. № 2168-VIII, Постанову Кабінету Міністрів України «Про утворення Національної служби здоров'я України» від 27.12.2017 р. № 1101-2017-п, це дало поштовх для укладання договорів 3 надавачами медичних послуг, впровадження розвитку організаційної структури 3 міжрегіональними департаментами та інше [2-4, 6, 9].

Середня очікувана тривалість життя у всьому світі становить 72 роки. За останні роки показник тривалості життя населення в Україні складає 68,25 року, при цьому в Польщі - 76,28 року, на Кубі - 77,45 року, у Великій Британії - 79,01 року, в Німеччині - 79,26 року і найвищий показник у Макао - 84,36 року. Причиною є незавершений процес рефрормування медичної галузі [1].

Мета роботи: здійснити порівняльний аналіз фрінансування сорери охорони здоров'я України та країн ЄC.

Матеріали і методи. Проведено дослідження на основі вивчення наукових джерел вітчиз- 
няних і зарубіжних вчених та контент-аналізу законів України, концепцій державних програм і резолюцій ЄС. Використано метод теоретичного порівняльного аналізу даних щодо моніторингу різними міжнародними групами реальної картини фрінансування сорери охорони психічного здоров'я в Україні та країнах ЄС.

Результати дослідження та їх обговорення. У 2015 р. Уряд України з метою зміцнення психічного здоров'я населення та забезпечення фрінансового захисту від надмірних витрат пацієнта «з кишені» на лікування ініціював реформу системи охорони здоров'я шляхом підвищення ефрективності, модернізації застарілої системи надання послуг та забезпечення якісного медичного обслуговування. Витрати «з власної кишені» за 2016 р. на одну людину (за ВВП) у США - 1094,2 долара; у Франції - 466,6 долара; у Великій Британії - 631,6; у Грузії - 443,2; в Україні - 290,3. Витрати «з власної кишені» у відсотках до всіх витрат на охорону здоров'я склали: у США - 11,1 \%; у Франції - 9,8 \%; у Великій Британії - 15,1 \%; у Грузії - 55,6 \%; в Україні - 54,3 \%. За даними опитування домогосподарств Міжнародним медичним корпусом за підтримки групи Світового банку, 90,7 \% стаціонарних пацієнтів сплачували за фрармацевтичні засоби «з власної кишені» $[7,10]$.

Після розробки та затвердження стратегії урядом, прийнято ряд нових законів України, які регулюють фрінансування системи охорони здоров'я (табл. 1).

Таблиця 1. Основні законодавчі та нормативно-правові документи, в яких регламентуються вимоги, що стосуються фрінансування сфери охорони здоров'я

\begin{tabular}{|c|c|}
\hline $\begin{array}{l}\text { № документа/рік } \\
\text { затвердження }\end{array}$ & Назва документа \\
\hline $1013-p / 2016$ p. & $\begin{array}{l}\text { Розпорядження Кабінету Міністрів України «Про схвалення Концепції ресрорми системи } \\
\text { орінансування охорони здоров'я» }\end{array}$ \\
\hline $180 / 2017 \mathrm{p}$. & $\begin{array}{l}\text { Постанова Кабінету Міністрів України «Про внесення змін та визнання такими, що } \\
\text { втратили чинність, деяких постанов Кабінету Міністрів України» (урядова програма } \\
\text { реімбурсації «Доступні ліки») }\end{array}$ \\
\hline 2168-VIII/2017 p. & Закон України «Про державні фрінансові гарантії медичного обслуговування населення» \\
\hline $2206-\mathrm{VIII} / 2017 \mathrm{p}$. & $\begin{array}{l}\text { Закон України «Про підвищення доступності та якості медичного обслуговування у } \\
\text { сільській місцевості» }\end{array}$ \\
\hline 1101-2017-ח/2017 p. & $\begin{array}{l}\text { Постанова Кабінету Міністрів України «Про утворення Національної служби здоров'я } \\
\text { України» }\end{array}$ \\
\hline $503 / 2018 \mathrm{p}$. & $\begin{array}{l}\text { Наказ МОЗ України «Про затвердження Порядку вибору лікаря, який надає первинну } \\
\text { медичну допомогу, та фрорми декларації про вибір лікаря, який надає первинну медичну } \\
\text { допомогу» }\end{array}$ \\
\hline $504 / 2018 \mathrm{p}$. & $\begin{array}{l}\text { Наказ МОЗ України «Про затвердження Порядку надання первинної медичної } \\
\text { допомоги» }\end{array}$ \\
\hline 407/2018 p. & $\begin{array}{l}\text { Постанова Кабінету Міністрів України «Про затвердження Порядку реалізації державних } \\
\text { гарантій медичного обслуговування населення за програмою медичних гарантій для } \\
\text { первинної медичної допомоги на } 2018 \text { рік» }\end{array}$ \\
\hline
\end{tabular}

У 2019 р. на охорону здоров'я було виділено 3 державного бюджету 98179 242,1 тис. грн (2,4 \% від ВВП), у той час, як, за рекомендацією Всесвітньої організації охорони здоров'я, потреба становила від 201760000 до 282464000 тис. грн (5-7 \% від ВВП).

На рисунку 1 показано відношення частки видатків на охорону здоров'я у ВВП (\%) до частки видатків на охорону здоров'я у видатках Зведеного бюджету України і до видатків на О3 у млрд грн у різні роки. Дані свідчать, що найбільше коштів на охорону здоров'я було спрямовано у 2013 р., оскільки частка видатків на ОЗ у ВВП становила 4,23 \%, тоді як у 2019 р. цей показник було визначено в два рази менше і становив 2,4 \% від ВВП. Такі різкі коливання у фінансуванні сорери охорони здоров'я негативно впливають на створення нової Національної служби здоров'я України (НСЗУ), на саму рефрорму в цілому [8].
При цьому в США на охорону здоров'я спрямовується 16,7 \% ВВП (при обсязі ВВП - 21,3 трлн дол. США), у Німеччині 11,1 \% (ВВП - 3,8 млрд дол. США), в Польщі - 4,86 \% (ВВП - 592 млрд дол. США), у Чехії - 7,4 \% (ВВП - 414 млрд дол. США), у Великій Британії - 9,8 \% (ВВП - 2830 млрд дол. США) та в Угорщині - 7,4 \% (ВВП - 161 млрд дол. США) [5].

Щодо видатків на охорону здоров'я із розрахунку на одну особу, то в 2019 р. США витрачало 10,8 тис. дол. США, на другому місці була Німеччина - 5,3 тис. дол. США, на наступному Велика Британія - 4,1 тис. дол. США, Чехія - 2,8 тис. дол. США, Угорщина - 1,2 тис. дол. США, Польща - 0,7 тис. дол. США і на останньому місці знаходиться Україна із розрахунком на одну особу 0,09 тис. дол. США (рис. 2).

3 вищенаведених даних видно, що потрібно забезпечувати стабільність розподілу бюджету 


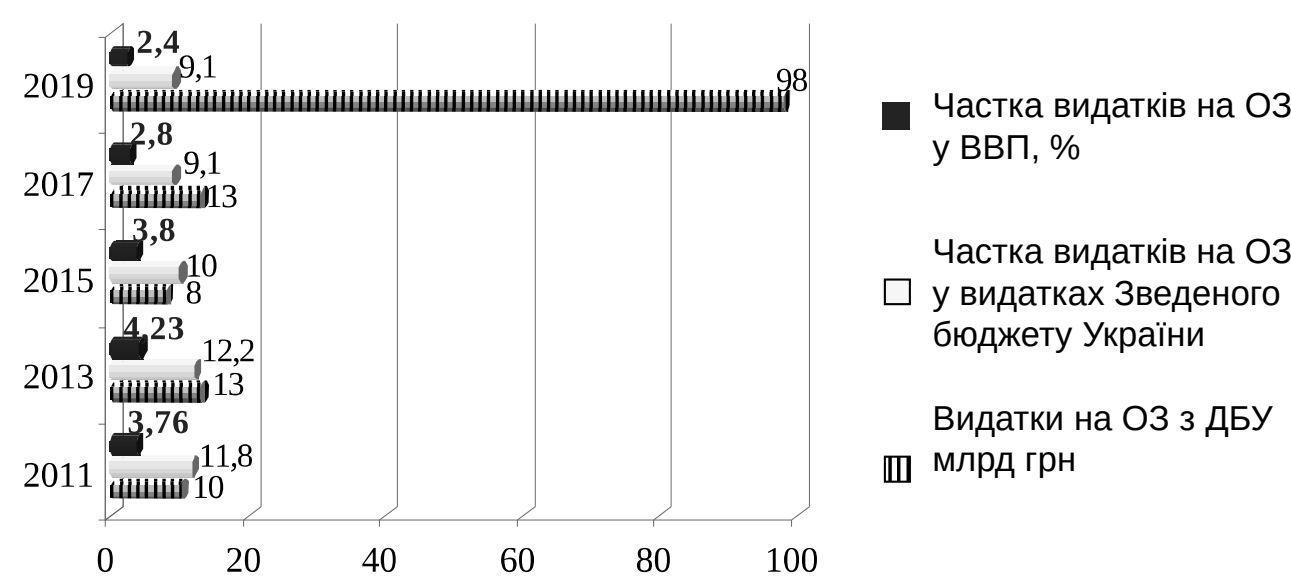

Puc. 1. Видатки на охорону здоров'я в Україні за 2011-2019 рр.

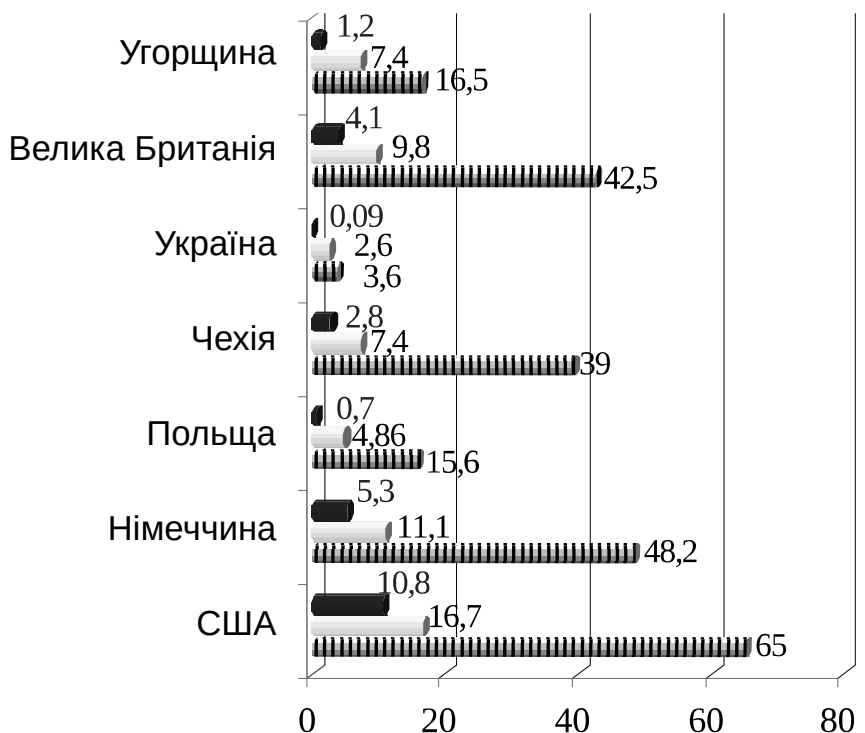

Видатки на О3

на одну особу,

тис. дол. США

Видатки на О3

у ВВП, \%

ВВП на одну особу,

Ш тис. дол. США

Puc. 2. Видатки на охорону здоров'я в Україні та країнах ЄС у 2019 р.

на охорону здоров'я в цілому, тому що це є запорукою успішного впровадження реформи системи охорони здоров'я і покращить якість надання медичних послуг. Оскільки, зважаючи на сучасну тенденцію до заощадження коштів на інвестицію у спектр охорони здоров'я, якість надання медичних послуг не змінюється, а отже, доступність даних послуг значно зменшується [11].

Якщо бюджет буде зменшено під час проведення реформ, спрямованих на підвищення ефективності, то ці кошти фрактично будуть виведені зі сорери охорони здоров'я і наслідком даних дій буде не лише те, що якість та стандарти медичного обслуговування залишаться на тому ж рівні, що і сьогодні, а й значно знизиться бажання медичних працівників та політиків у подальших реформах, що, у свою чергу, призведе до занепаду української медицини в цілому. Відносно високий рівень індляції може спричинити зниження купівельної спроможності бюджетних видатків, тому це вже завдання Міністерства фрінансів України, яке повинно забезпечити достатнє фрінансування для реалізації всіх запропонованих у рефор- мі змін. I тому має бути тісна співпраця між Міністерством охорони здоров'я України, НСЗУ та Міністерством фрінансів України. Додаткові бюджетні влиття в систему охорони здоров'я повинні бути зіставлені з економічними і фріскальними умовами в країні. Фінансування громадського здоров'я має здійснюватися в повному обсязі 3 визначенням пріоритетних сорер. Через певні обмеження у фріскальному просторі ми маємо ряд вимог для більш ретельного визначення пріоритетів у рамках бюджету на охорону здоров'я з чітким визначенням пріоритетів державної політики в обраній сорері. Витрати на первинну ланку медичної допомоги зросли, що відображає зусилля медичних працівників і політику держави на даному рівні надання медичних послуг.

Інтеграцію реформи на вторинній і третинній ланках допомоги потрібно проводити поетапно відповідно до можливостей бюджетних ресурсів. При бюджетному розподілі мають проводити чітку розробку витрат, що надасть можливість абсолютно точно окреслити пріоритети в межах даного розподілу. Уряд вже визначився з пріо- 
ритетними станами та послугами, включаючи до цього переліку вагітність та пологи; неінфекційні захворювання (астма, хронічне обструктивне захворювання легень, ішемічна хвороба серця, діабет 2 типу та онкологія); інсрекційні захворювання (вакциноконтрольовані захворювання, ВІЛ, туберкульоз, гепатити В і С). Даний перелік ґрунтується на таких детальних критеріях, як економічна ефективність та результативність даних послуг, потреба в даних послугах, рівноправність доступу населення та його захист.

Позитивний момент у реформі на прикладі Республіки Польща $€$ відокремлення цільових коштів на охорону здоров'я від бюджету і це дає можливість запобігти «провалам» бюджету. Органам місцевого самоврядування належить $99 \%$ закладів охорони здоров'я у Польщі та близько 30 закладів, які підпорядковані МОЗ Польщі. Але у Республіці Польща з 1997 р. прийнято закон про обов'язкове медичне страхування як у багатьох країнах світу. Психічне здоров'я населення Польщі та країн ЄС $€$ одним із пріоритетних завдань і невід'ємною частиною у реформуванні сорери охорони здоров'я [1].

\section{Висновки}

Як свідчать усі наведені у статті дані, фрінансових ресурсів у сорері охорони здоров'я не вистачає. Недосконалість фрінансування зумовлює втрату комплексності та черговості у наданні медичної допомоги, нераціональну організацію надання медичної допомоги. Без достатніх фрінансових надходжень якість, кількість та доступність медичних послуг не лише не покращуються, але й мають тенденцію до регресії. При розподілі державного бюджету і виділенні коштів на сферу охорони здоров'я наша держава повинна рівнятися на прогресивні європейські країни. Для такої масштабної/всебічної трансформації системи охорони здоров'я України щодо реконфрігурації інфраструктури надання медичних послуг необхідно постійно під час впровадження проводити коригування/моніторинг ефективності надавачів, але без шкоди діючої нової моделі фрінансування системи охорони здоров'я, і ввести обов'язкове медичне страхування.

Перспективи подальших досліджень пов'язані з вивченням фрінансування і проведенням реформи в сфрері охорони здоров'я України.

\section{Список літератури}

1. Гайдаш Д. С. Фінансування системи охорони здоров'я Польщі: досвід для України / Д. С. Гайдаш // Актуальні проблеми державного управління. - 2015. - № 1 (47). - С. 339-346.

2. Звіт Національної служби здоров'я України за 2019 р. [Електронний ресурс]. - Режим доступу : https://nszu.gov. ua/gromadyanam/zviti-nszu.

3. Про державні фрінансові гарантії медичного обслуговування населення : Закон України від 19.10.2017 р. № 2168-VIII [Електронний ресурс]. - Режим доступу : https://zakon.rada.gov.ua/laws/show/2168-19\#Text.

4. Про утворення Національної служби здоров'я України : Постанова Кабінету Міністрів України від 27 грудня 2017 р. № 1101-2017-п [Електронний ресурс]. - Режим доступу : https://zakon.rada.gov.ua/laws/show/1101-2017\%D0\%BF\#Text.

5. Солдатенко О. Сучасний стан правового регулювання фрінансування сфери охорони здоров'я України / О. Солдатенко // Підприємство, господарство і право. - 2018. - № 2. - С. 142-147.

6. Україна: огляд рефрорми фрінансування системи охорони здоров'я 2016-2019 : Спільний звіт ВООЗ та Світового банку [Електронний ресурс]. - Режим доступу : https://www.euro.who.int/_data/assets/pdf_file/0018/425340/WHOWB-Joint-Report_UKR_Full-report_Web.pdf.

7. Чорна В. В. Рефрормування охорони здоров'я для зміцнення психічного здоров'я населення України та досвід країн ЄС / В. В. Чорна // Вісник Вінницького національного медичного університету. - 2020. - № 24 (3). - С. $447-456$. DOI: 10.31393/reports-vnmedical-2020-24(3)-11.

8. Шевченко М. В. Загальні витрати на охорону здоров'я в Україні (за даними національних рахунків охорони здоров'я) / М. В. Шевченко // Україна. Здоров'я нації. - 2010. - № 2 (14). - С. 84-88.

9. Comparative analysis of morbidity indicators among the population of the EU and Ukraine under conditions of stressed load of the anti-nerrorist operations and psychoprophylaxis measures / V. Chorna, V. Makhniuk, N. Gumeniuk, S. Khliestova, A. Tomashevskyi // Georgian medical news. - 2020. - No 5 (302). - P. 147-154.

10. Mental health in transition: evaluation results and recommendations for the integration of mental health into the primary care system and community platforms in Ukraine. International Medical Corps with the support of the World Bank Group. documents.worldbank.org > 120767-Ukrainian-PUBLIC-mental-health-UA ipz.org.ua > uploads > 2018/01 > MH-report-for_ INTERNET_All_ua.

11. Roland $M$. How financial and reputational incentives can be used to improve medical care / M. Roland, R. A. Dudley // Health Services Research. - 2015. - Vol. 50 (Suppl 2): 2090 - 115. DOI: 10.1111/1475-6773.12419

\section{References}

1. Gaidash D.S. (2015). Finansuvannia systemy okhorony zdorovia Polshchi: dosvid dlia Ukrayiny [Polish health care financing of Poland: an experience for Ukraine]. Aktualni problemy derzhavnoho upravlinnya - Actual Problems of Public Administration, 1(47), 339-346 [in Ukrainian].

2. Zvit Natsionalnoyi sluzhby zdorovia Ukrayiny 2019 [Report of the National Health Service of Ukraine 2019]. nszu.gov.ua. Retrieved from: https://nszu.gov.ua/gromadyanam/zviti-nszu [in Ukrainian]. 
3. (2017). Pro derzhavni finansovi harantiyi medychnoho obsluhovuvannya naselennya. Zakon Ukrayiny vid 19.10 .2017 No 2168-VIII [About the state financial guarantees of medical service of the population. Law of Ukraine of 19.10 .2017 No 2168-VIII]. zakon.rada.gov.ua. Retrieved from: https://zakon.rada.gov.ua/laws/show/2168-19\#Text [in Ukrainian].

4. (2017). Pro utvorennya Natsionalnoyi sluzhby zdorovia Ukrayiny. Postanova Kabinetu Ministriv Ukrayiny vid 27 hrudnya 2017 r. No 1101-2017-p [On the establishment of the National Health Service of Ukraine. Resolution of the Cabinet of Ministers of Ukraine of December 27, 2017, No 1101-2017-n]. zakon.rada.gov.ua. Retrieved from: https://zakon.rada.gov. ua/laws/show/1101-2017-\%D0\%BF\#Text [in Ukrainian].

5. Soldatenko, O. (2018). Suchasnyy stan pravovoho rehulyuvannya finansuvannya sfery okhorony zdorovia Ukrayiny [The current state of legal regulation of health care financing in Ukraine]. Pidpryyemstvo, hospodarstvo i pravo - Enterprise, Economy, and Law, 2, 142-147 [in Ukrainian].

6. Spilnyy zvit VOOZ ta Svitovoho banku. Ukrayina: ohlyad reformy finansuvannya systemy okhorony zdorovia 2016-2019 [Joint report of the WHO and the World Bank. Ukraine: A Review of Health Care Financing Reform 2016-2019]. www.euro. who. Retrieved from: https://www.euro.who.int/_data/assets/pdf_file/0018/425340/WHO-WB-Joint-Report_UKR_Fullreport_Web.pdf [in Ukrainian].

7. Chorna, V.V. (2020). Reformuvannya okhorony zdorovia dlya zmitsnennya psykhichnoho zdorovia naselennya Ukrayiny ta dosvit krayin YES [Health care reform to strengthen the mental health of the population of Ukraine and the experience of EU countries]. Visnyk Vinnytskoho natsionalnoho medychnoho universytetu - Bulletin of Vinnytsia National Medical University, 24(3), 447-456 [in Ukrainian].

8. Shevchenko, M.V. (2010). Zahalni vytraty na okhoronu zdorovya v Ukrayini (za danymy natsionalnykh rakhunkiv okhorony zdorovia) [Total health expenditures in Ukraine (according to national health accounts) Ukraine]. Ukrayina. Zdorovia natsiyi - Ukraine. Health of the Nation, 2(14), 84-88 [in Ukrainian].

9. Chorna, V., Makhniuk, V., Gumeniuk, N., Khliestova, S. \& Tomashevskyi, A. (2020). Comparative analysis of morbidity indicators among the population of the EU and Ukraine under conditions of stressed load of the anti-nerrorist operations and psychoprophylaxis measures. Georgian Medical News, 5(302), 147-154.

10. Mental health in transition: evaluation results and recommendations for the integration of mental health into the primary care system and community platforms in Ukraine. International Medical Corps with the support of the World Bank Group. documents.worldbank.org > 120767-Ukrainian-PUBLIC-mental-health-UA ipz.org.ua > uploads > 2018/01 > MH-report-for_ INTERNET_All_ua

11. Roland, M., \& Dudley, R.A. (2015). How financial and reputational incentives can be used to improve medical care. Health Services Research, 50 (Suppl 2), 2090-2115. doi: 10.1111/1475-6773.12419

\section{COMPARATIVE ANALYSIS OF HEALTH FINANCING IN UKRAINE AND EU COUNTRIES}

V. V. Chorna

M. Pyrohov National Medical University, Vinnytsia, Ukraine

Purpose: to carry out a comparative analysis of the financing of health care in Ukraine and the EU countries in recent years.

Materials and Methods. Theoretical-comparative, bibliosemantic analysis of data on health care financing in Ukraine and EU countries has been using.

Results. Scientific sources of domestic and foreign research, Laws of Ukraine, Concepts of state programs, and EU resolutions are analyzed, and the main problems of incomplete medical reform have been highlighting. Several regulations have been adopted in Ukraine to implement health care reform successfully. Positive changes in health care reform Ukraine is directly dependent on health expenditures in GDP. A sizeable amount of funds has spent on health care in $2013-4,23 \%$, but in 2019 this figure was the lowest in the last years of independence $2,4 \%$ of GDP. Sharp fluctuations in the financing of health care hurt the creation of the new National Health Service of Ukraine, on the reform as a whole, as well as on the life expectancy of the population in Ukraine. Positive examples in the health care reform of both the Republic of Poland and other European countries are the separation of targeted funds for mental health care from the budget, which belong to local governments of health care institutions, and the much-needed law on compulsory health insurance in many countries around the world. The mental health of the population of Poland and the EU is one of the priorities and an integral part of health care reform. The resolution of the WHO, the Council of the EU, the Council of Europe since 1975 emphasizes the importance of adequate and fair investment in the mental health system, which affects the health of the world's population. In 2019, the WHO and the World Bank analyzed the reform of health care financing for 2016-2019 to provide strategic recommendations for improving the provision of medical services.

Conclusions. According to the results of the analysis, the imperfection of financing of the $\mathrm{CHC}$ of Ukraine was established, which affects the quality of medical care and the need to regularly adjust/monitor the effectiveness of the new model of financing the health care system of Ukraine and the introduction of compulsory health insurance.

KEY WORDS: financing; health care; mental health; health care reform.

Рукопис надійшов до редакції 22.12.2020 p.

Відомості про автора:

Чорна Валентина Володимирівна - кандидат медичних наук, доцент кафедри медицини катастрофр та військової медицини Вінницького національного медичного університету імені М. І. Пирогова; тел.: +38(067) 919-40-38. 